\title{
Communication Bridges between Religion and Science: Route Saint Augustine - Blaise Pascal
}

\author{
Daniela Manolea \\ High School "Henri Coandă”, 48 Henri Coandă Street, Craiova, Romania \\ E-mail address: danimanolea@yahoo.com
}

\begin{abstract}
This study examines the flow of ideas that led to the final separation of religion and science. The research found that route, which occurred this segregation has the obligatory points of passage in Saint Augustine and Blaise Pascal. Decisively, the two contribute to the gradual release of pressing close personal ego exercised by universal self. Science and religionseparation begins with the right human desire to be free, with the idea of freedom. The Pascalian "I" is actually a human presence in the center of discourse. Saint Augustine, nor Pascal does not apply "generally to man". They know that always the faith comes to a person in his singularity and his historical context.
\end{abstract}

Keywords: idea of freedom; liberty of thinking; religion discourse; scientific discourse

\section{INTRODUCTION}

From the apologists of the first centuries to Maurice Blondel or Pierre Teilhard de Chardin, a many geniuses and saints have marked the history of Christian apologetic thought. Today, the question of God goes more than ever by everyday problems and existential of the human, and religious pluralism, and exposes us to a double temptation of indifference and identity crisis. In this area Pascal is the main heir of Saint Augustine. In the field of apologetics, writes Philippe Sellier (Sellier, 2009), Pascal has only a master outside of Jesus Christ who is Saint Augustine. Pascal finds Saint Augustine in the alive consciousness, in which the apologetic approach employs first that one who is proposed.

The Pascal's work abounds "I". "What ought I to do? I see only darkness everywhere. Shall I believe I am nothing? Shall I believe I am God?" (Pascal, 1950). It is not only individual psychological nor a rhetorical "I" with literary effect, Pascal hates effluvia of "I". The Pascalian "I" is actually a human presence in the center of discourse. Certainly, this "I" does not designate this particular individual, but is universalizing and is approaching of the companion as a kind of essential empathy. Giving the word its interlocutors, Pascal is identified somehow with their own search (Sellier, 1970; Smarandache \& Vlăduțescu, 2012).

On the other hand, neither Saint Augustine, nor Pascal does not apply "generally to man". They know that always the faith comes to a person in his singularity and his historical context.

Pascal choose the letter as a literary form excellencey of "brief relationship", reduced to the exchange of ideas, opinions between the author and the recipient. This recipient is qualified with the term of "friend". Such intersubjective space is open to friendship and friendly controversy. This is the space of counsel and not of imperative, that is the closest to the 
Pascalian "soul" where are prepared and are set the decisive choices. In fact this response contains the recipient relationship with God. Regard this Pascal is Augustinian (Sellier, 2006; Buşu, 2013).

Augustine's apologetic texts does not pretend to give the faith to interlocutor, but prepare the ways, removing obstacles, and awake the desire. One and the other, know well that reasoning alone could not produce a demonstration of Christian truth. Pascal has an alive consciousness, namely that the soul is that feels God and not the "reason" (Gilson,1987; Adămuț, 2001; Vlăduțescu, 2004a).

\section{FROM APOLOGETICS TO THE PHILOSOPHY AND SCIENCE}

In „De utilitate credendi”, Saint Augustine put his seduction exerted by manichaeism (dualism $=$ dualistic conception of good and evil as two opposing forces) directly related claiming this sect to explain everything rationally, without resorting to authority.

Pascal knows from experience that will never believe if God will not penetrate his soul. In Letter 118 to the Dioscuri, Saint Augustine is more categorical: to understand and master the truth there is no other way, "than that one that was open by that, like God, saw our weakness and uncertai nty of oursteps. The first of these ways is humility. The second is humility. The third is also humility" (Augustin, 1991). The claimed humility to recipient is the first of the author and is translated very concrete and by resorting to prayer. In this sense, a true Christian finds the strength in silence of the intimate dialogue with God. "It ought to sit in silence as much as is possible and to not talk only with God who we know that is the truth, and so to get inside Him. "Out of this dialogue, everything is rhetoric. The prayer becomes the higher place of a spiritual fight, in which the author and the recipient have the opportunity to discern and to purify (to clear) the intentions (Vlăduțescu, 1995; Vlăduțescu, 2004b; Stoienoiu, 2004). Pascal is opting instead for a kind of spiritual psychoanalysis of the recipient. He says: people have contempt for religion. Sometimes they hate it. They fear it is true (Tat, 2005; Freytag, 2013). To cure them of this we must start by showing them that "religion is not contrary to reason". In this open space, the rational debate on "the true religion" (Augustine, 1950) on "the evidence of the Christian religion" (Pascal) can be effectively introduced (Pascal, 1967).

Augustine, true self experience, sees in the Christian religion "the true philosophy". To describe the Christian religion, "benevolent", "kind", it will show that it "promises to keep his promise", destination will be so the fulfilling of the human desire to greet "the Savior" Jesus Christ. For each of them, human becoming makes sense only through revealed historicity that is joined between the original sin drama and the salvation brought by Jesus Christ. Instead, the actual reality of this revealed historicity is attested by historical coming of Jesus Christ and empirical traces of sin easy to find, reality that only original sin and salvation can only make them understandable to reason. Thus Augustine writes: "the highest grade of the whole authority and the most vivid light of reason are joined in only Savior's name, that of Jesus Christ and within the pale of His Church, for reform and regeneration of the human race". Pascal: "Jesus Christ is the goal of everybody and the center to which tends everything" (Pascal, 1968).

Augustine, in his dialogue with pagan philosophy and dualists, is based on Platonic rationality to show that Christianity is both "true philosophy" and "true religion".

Not the reading of the neoplato philosophers "warns to turn to himself" and releases him of the intellectual obstacles that paralyzed the understanding of the mysteries of God? Therefore it is the Platonic schema of the soul coming back into itself to overcome in the transcendental 
that will be the the rational support of the apologetic approach: from sensitive to intelligible, from changing to the constant, from multiple to single (Borowski, 2013a; Vlăduțescu, 2006a).

Saint Augustine calls also other intellectual scheme of the era, the inherited one rather of stoicism, that categorizes philosophy in: moral, physical, logical.

Each of these texts shows that the Christian religion respects each side to the full and so philosophy is "the true philosophy". Thus, in "De vera Religion" St. Augustine shows the connection we have with Jesus Christ, who has assumed, by His incarnation, the whole man, so to be able to save him in his entirety. He develops this assertion in three steps: the evocation of the Jesus's life - "disciplina morum" through which is performed the ethical; His resurrection "disciplina naturalis" through which the physics, as theory of nature, revealing the divine goodness and substantiality of creation (Rizea, 2005). Finally Teachings of Jesus through which is performed "the ideal of a discipline of reason" - "rationalis discipline regula" - that is logic.

Pascal knows well the Augustinian argument (Sellier, 2009; Vlăduțescu, 2006b; Bușu, 2013). He resumes in his exclusively apologetic work, intellectual patterns that he applied in his scientific work and shared them with his recipients. We actually find here, as a recurring schedule, looking for a fixed point, determined in physical problems - ("Traites de l'Equilibre des liqueurs") and geometry ("Problemes concernant the Cycloid. Histoire de la roulette"). Either we talk about cosmology, moral life or writing intelligence, rational challenge is everywhere the same: "it has to be found the point", center of the perspective and balance, where all is ordered and makes sense. "There is only one indivisible point which is the true place". Or "never, anybody got to this point without faith".

The apologetic work consist in explaining this failure and demonstrating that only faith can overcome it (Vlăduțescu, 2008; Vlăduțescu, 2009). "Jesus Christ is the goal of everybody and the center toward tends all". To get here, Pascal applies the second rational scheme extracted directly from his scientific work: "the ration of effects". That is about returning effects to their causes, in a dynamic mode even dialectical. We can say that the same cause may entail, if other conditions vary or change the position of the observer, different effects. Similarly to air pressure that takes into account the conflicting constants regarding fluid balance, we must be able to consider, "barriers, opposites, contradictions if you will, that make so enigmatic the human condition" (Arhip \& Arhip, 2012). We should, by taking into account assembly of the factual data of the problem, be able to formulate the hypothesis, which will explain best these facts.

Christian faith will be presented as a clear hypothesis for the understanding of this contradictory given fact that is the human being divided between greatness and his misery (Watson, 2011; Borowski, 2013b). Here we can easily see Pascal's originality.

If Saint Augustine had seen in Christianity, at the cost of a transformation of pride in humility and of the reason in history, the achieving of each from the parts of philosophy, Pascal will highlight the radical nature of contradictions which prohibit each of these parts to satisfy reason. He makes of these obstacles even the lever of the reason, which "leads to the Christian assumption". Such new physics makes the human being impossible to be situated from the point of view of cosmological in a universe without landmarks, in a cosmos which has only, "eternal silence of his infinite spaces".

Despite the radicalism of some of his formulas, Pascal concludes that only "the paths opened by the Gospel" offer a genuine exist out of his senses searching, giving him the key of the code: the source of contradictions for a both humble and dignified God in His death on the Cross. Two existing natures in Jesus Christ. Two comings of The Savior. Two states of the human nature. A triumphant Messiah over death, through His death. Pascal confirms without 
doubt the Oliver Clement's word: "The Resurrection is the only reasonable element of a history without She, absurd".

The basis of The Holy Bible that comes through each apologetic approach from today or from yesterday is contained within IP 315: "Be always ready to share the hope that lies in you to those who seek justice from you ".

\section{CONCLUSION}

The two authors invite us to dig deeper into the permanent truth of human being to touch and to excite the soul, ours and that of our companion, but also to pay attention to rational schemes, studied from a historical point of view, of which contemporary intelligence dispose, not to put them at the service of the outside Gospel, which would be artificial and forced, but to work with them from the inside of their own beliefs in the service of the Gospel. We must also be ready to face, "existential obstacles (contradictions)" of the contemporary world turned infinitely more complex than Augustinian or Pascalian world. We will succeed only if we go in the depth of the human soul and to the essence of our faith.

\section{References}

[1] Arhip C., Arhip O., Annales Universitatis Apulensis. Series Philologica 13(1) (2012) 7-36.

[2] Augustine S. (1950). The city of God. New York: Modern Library.

[3] Augustine S. (1991). Confessions. Oxford: Oxford University Press.

[4] Adămuţ A. I. (2001). Filosofia Sfântului Augustin. Iași: Editura Polirom.

[5] Borowski Andrzej (a). International Letters of Social and Humanistic Sciences 6 (2013) 68-74.

[6] Borowski Andrzej (b). International Letters of Social and Humanistic Sciences 7 (2013) 113-118.

[7] Buşu O. V., European Journal of Business and Social Sciences 2(6) (2013) (2013).

[8] Dima I. C., Vlăduțescu Ștefan (2012). Persuasion Elements Used in Logistical Negotiation: Persuasive Logistical Negotiation. Saarbrucken: LAP Lambert.

[9] Freytag Stefan, International Letters of Social and Humanistic Sciences 10 (2013) 25-31.

[10] Gilson E. (1987). Introduction à l'Étude de Saint Augustin. Paris: Vrin.

[11] Manolea D., European Scientific Journal 9(28) (2013) 54-62.

[12] Stoenoiu R., Revista Literară Vatra (01-02) (2005) 171-172.

[13] Tat A., Studia Universitatis Babes Bolyai-Theologia Catholica 1 (2005).

[14] Rizea C., Analele Universității din Craiova (2005) 111.

[15] Pascal B. (1967). The provincial letters. London: Penguin.

[16] Pascal B. (1968). Pensées. London: Penguin. 
[17] Sellier P. (1970). Pascal et Saint Augustin. Paris: Armand Colin.

[18] Sellier P. (2006). Pascal auteur spirituel. Paris: Champion.

[19] Sellier P. (2009). Pascal. Paris: Seuil.

[20] Smarandache Florentin, Vlăduțescu Ştefan (2012). Extension communication for solving The ontological contradiction between communication and information. In F.

Smarandache (Ed.), Extensics in higher dimensions (pp. 99-112). Columbus, OH: Education Publisher.

[21] Vlăduțescu Gheorghe (1995). Filosofia primelor secole creștine. Editura Enciclopedică.

[22] Vlăduțescu Ştefan (2002). Informaţia de la teorie către ştiinţă. Propedeutică la o ştiinţă a informaţiei.Bucureşti: Editura Didactică şi Pedagogică.

[23] Vlăduțescu Ștefan (2004a). Comunicologie și Mesagologie. Craiova: Editura Sitech.

[24] Vlăduțescu Ştefan (2004b). Argumentaţia şi demonstraţia, ca moduri de impunere. Craiova: Editura Sitech.

[25] Vlăduțescu Ștefan (2006a). Comunicare și mesaj în filozofie. Craiova: Editura Sitech.

[26] Vlăduțescu Ştefan (2006b). Comunicarea jurnalistică negativă. București: Editura Academiei.

[27] Vlăduțescu, Ștefan (2008). Comunicarea managerială negativă în activitatea publi cistică. Craiova: Editura Arves.

[28] Vlăduţescu Ştefan (2009). Concepte şi noţiuni de Comunicare şi Teoria mesajului. Craiova: Editura Sitech.

[29] Vlăduțescu Ștefan, Ciupercă Ella Magdalena (2013). Next Flood Level of Communication: Social Networks. Aachen: Shaker Verlag.

[30] Watson R. N. (2011). Back to Nature: The Green and the Real in the Late Renaissance. University of Pennsylvania Press. 